\title{
A case of hereditary persistence of fetal haemoglobin
}

\author{
Manouri P Senanayake ${ }^{1}$, Dumindu H Ratnaweera ${ }^{2}$, Sanath P Lamabadusuriya ${ }^{3}$ \\ Sri Lanka Journal of Child Health, 2004; 33: 119-20
}

(Key words: hereditary persistence of fetal haemoglobin, HPFH)

\section{Introduction}

Thalassaemia syndromes comprise a large clinical spectrum and a well recognized observation is the inverse link between clinical severity and quantity of fetal haemoglobin $(\mathrm{HbF})$ present $^{1}$. It is now known that three types of globin that produce haemoglobin $(\mathrm{Hb})$ change from e-globin (epsilone) to g-globin (gamma) in the fetus and to b-globin (beta) around birth. This process of change is termed "globin switching". Rarely, due to a genetic defect, the gglobin gene continues to function, producing gamma chains. Therefore $\mathrm{HbF}$ is present throughout life giving rise to the condition hereditary persistence of fetal haemoglobin $(\mathrm{HPFH})^{2}$. Such persons are often asymptomatic and lead normal lives. Persons with thalassaemia major who have concomitant $\mathrm{HPFH}$ have low transfusion requirements due to the persistence of $\mathrm{HbF}$, making up for the deficiency of b-globin ${ }^{3}$. HPFH provides a basis for a genetic approach to cure haemoglobinapathies in the future.

\section{Case report}

A 9 year old girl from the south of Sri Lanka presented to us, at the age of 9 years, with pallor and hepatosplenomegaly. She was the product of a non consanguineous marriage and a maternal uncle had died at the age of 20 years due to "thalassaemia". No other details were available.

She had been well until five years when she presented to the local hospital with fever, jaundice, pallor, hypochromic microcytic anaemia with target cells, a positive alkaline denaturation test and absence of bile in the urine and received a blood transfusion. A similar episode one year later resulted in the diagnosis of thalassaemia intermedia being made. Menarche at 9 years was followed by fever, enlarged liver and spleen of $3 \mathrm{~cm}$ and $2 \mathrm{~cm}$ respectively.

${ }^{1}$ Professor and Head,Dept. of Paediatrics, University of Colombo, ${ }^{2}$ Senior Registrar, Professorial Paediatric Unit, Lady Ridgeway Hospital, Colombo, ${ }^{3}$ Chair and Senior Professor of Paediatrics University of Colombo.
We found the following haematological findings: $\mathrm{Hb}$ 6g\%, MCH $22 \mathrm{pg}$, MCV $63 \mathrm{fl}$, MCHC $35 \mathrm{~g} / \mathrm{dl}$; white cell count $9.2 \times 10^{9} / 1(\mathrm{~N} 50 \%, \mathrm{~L} 45 \%, \mathrm{E} 3 \%$, M2\%); platelets $235 \times 10^{9} / 1$; reticulocyte count $4.2 \%$.

Blood picture showed hypochromic markedly distorted red blood cells with anisocytes, poikilocytes, microcytes, target cells, spherocytes, fragmented and crenated cells, polychromatic cells and normoblasts. White cells and platelets were normal.

Alkaline denaturation test was positive with $37 \%$ $\mathrm{HbF}$.

Acid elution test was $95 \%$ positive in neonatal blood (positive control), $100 \%$ negative in adult blood (negative control) and almost $100 \%$ positive in patient's blood.

Haemoglobin electrophoresis detected only $\mathrm{HbF}$ with no adult $\mathrm{Hb}$ or $\mathrm{Hb} \mathrm{E}$. Coombs test and sickling test were negative. G6PD test showed normal enzyme activity. Osmotic fragility showed initial haemolysis at $0.5 \%$ and not completed at $0.1 \%$.

Mother's and father's blood showed alkaline denaturation tests of $1.2 \%$ and $0.9 \%$ and $\mathrm{Hb} \mathrm{A} 2$ levels of $3.1 \%$ and $2.6 \%$ respectively. A diagnosis of HPHF was made. She remained well until 14 years when she needed her fourth transfusion.

\section{Discussion}

Our patient had a non transfusion dependent chronic haemolytic anemia and presented with a fragmentation syndrome in the blood picture due to an acute crisis of haemolysis precipitated by an intercurrent febrile illness. Her $\mathrm{Hb}$ electrophoresis result indicates HPFH or homozygous thalassaemia with HPFH.

Increased levels of fetal haemoglobin (HbF) can ameliorate the clinical course of inherited disorders of beta globin gene expression, such as beta thalassaemia and sickle cell anaemia ${ }^{4}$. The continued production of $\mathrm{Hb} \mathrm{F}$ compensates for the lack of $\mathrm{Hb}$ 
$\mathrm{A}^{5}$. A search for drugs to activate fetal haemoglobin production as a treatment option for thalassaemia and sickle cell disease is underway although clinical trials with hydroxyurea and butyrate have not yielded success ${ }^{6}$. Attempts to suppress the repressor proteins that bind to g-globin genes are being researched.

\section{References}

1. Marcus S J, Kinney $\mathrm{T}$ R, Schultz W H, O'Branski E E, Ware R E. Quantitative analysis of erythrocytes con-taining fetal hemoglobin (F cells) in children with sickle cell disease. American Journal of Haematology 1997; 54(1): 40-6.

2. Little J A, Dempsey N J, Tuchman M, Ginder GD. Metabolic persistence of fetal hemoglobin, Blood 1995: 85(7): 1712-8.
3. Papadakis M N, Patrinos G P, Tsaftaridis $P$, Loutradi-Anagnostou A. A comparative study of Greek non deletional hereditary persistence of fetal hemoglobin and beta thalassaemia compound heterozygotes. Journal of Molecular Medicine 2002; 80(4): 243-7.

4. Forget B G, Molecular basis of hereditary persistence of fetal hemoglobin. Annals of New York Academy and Sciences 1998; 850: 38-44.

5. Ho P J, Hall G W, Luo LY, Weatherall D J, Thein S L. Beta thalassaemia intermedia: is it possible consistently to predict phenotype from genotype? British Journal of Haematology 1998; 100(1): 70-8.

6. Baliga B S, Pace B S, Chen H H, Shah A K, Yang Y M. Mechanism for fetal hemoglobin induction by hydroxyurea in sickle cell erythroid progenitors. American Journal of Hematology 2000; 65(3): 227-33. 